\title{
末端位数の分布加らみ測定值の評価
}

\author{
川原叻 り*渡辺俊男** 松下清子*** \\ (昭和50年 9 月 5 日 受付)
}

\section{Evaluation of Various Kinds of Measurement Applying a Hypothesis of Even Distribution of Last Digit in the Recorded Numbers}

\author{
Yuri KAWAHARA (Rissho University) \\ Toshio WATANABE (Yokohama National University) \\ Kiyoko MATSUSHITA (Yokohama Midorigaoka Senior High School)
}

大数例の計測を行なう場合, その数值が $3 〜 4$ 析以上飞なるときは, 末端位の数は理論的に0〜9まで平等に 出現するはずである。

諸種の計測, 計量值すなわち人口数, 温度溳定值, 身長, 体重, 血圧などを計浿した結果, その値の末端位数 の分布が, 理論的分布と一致しているか否かを， $x^{2}$-test Kよって確かめ，計測の難易度，精度及び被涀定者の 管理状態の良否について検討した。

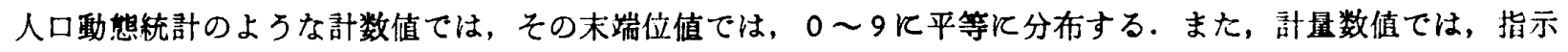
目盛を固定し得るものに比して，動摇中に测定值を読みとらなりればならない場合は，末端位数はより多く○と 5 㴜って集まる，とくに体重の测定值では，被測定者の年令が進むとつれて，末端位数が 0 と 5 亿集中する傾 向が著しく，测定に対する計測者扣よび被測定者の安易な態度がうかがわれる。

The appearance of the last digit of any number, composed of several digits, as a result of a measurement out of large number of samles, is expected to be evenly distributed between figures zero and nine. Variety of measurement results, such as population, reading in thermometer, height, weight and blood pressure, were collected in order to ascertain the hypothesis above by applying $\chi^{2}$-test. This, in turn, would mean an examination of validity and reliability in administration of data.

The hypothesis was proved to be correct in the cases of demographic values. Among the measurement recordings, the last digit appeared more frequently to be figures zero and five, when the value had to be momentarily recorded as the dial indicator was not well fixed, than the cases when it could be fixed.

The body weight readings showed this trend most greatly as the age of subjects advanced. The results indicate the unstrict attitude of the tester and the subject towards accurate measurement under certain circumstances.

(Yuri KAWAHARA, Toshio WATANABE, and Kiyoko MATSUSHITA: Evaluation of Various Kinds of Measurement Applying a Hypothesis of Even Distribution of Last Digit in the Recorded Numbers. Research Journal of Physical Education, Vol. 20, No. 4, Feb., 1976, pp. 203 212), 


\section{I.}

科学的な記述は，量化されたものの基礎によら なければならない，物理量の湖定では，しばしば 技術的な困難さにつきあたるが，心理的なものの 量化は印つけのむすかしさにある。最近では，心 理的計㣜法 (psychometics) $)^{6}$ が開発されつつあ り，社会科学などで取扱われる調查や統計も，物 理的な量を测定する場合と同じょ5にある「印つ け」されたものの量化を試みよらとしている。

ほとんどの計器は視喾によって読みとられてい るが，その判断や認知に際しては，単に感賞たけ ではなく，人間の特徽である選択能力や帰納的・ 演繹的な能力をも必要とするので，視觉表示と人 間側の態度についても論じられなければならな (.13)このよ5にして問題は機械を選ぶか人を元 らふかが存在し，その何れも無視できないもので ある. ${ }^{8}$

与件の計測には計数的なものと計量的なものと があり, 計量的計测はフナログ的なものをデジタ ル的な数量に変換するすのであり，その間におけ る枟換の妥当性如何によって器差が生じてくる.

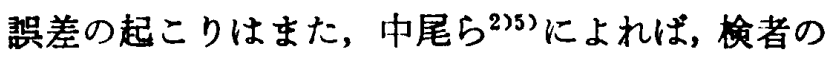
能力, 計器の目盛線と幅の関係及び計測值の析数 などにもよるとされ，計剆值の信頼度についても 報告されている。

本報告では，諸種の計量にあたって生ずる器差 の在り方を論じこれによって計測の团難度を計 測者及び被椡定者（物）の側から検討し，計测の 正確さと犃差の由来を考察したものである。

\section{II. 酯查方法}

元来，計測はそれを行な5こととに血差を生ずる ものであるが，その留差の出現はガウス (Gauss) の築差法則にしたが5ものであろう。

例えば 3 析の数 $100 l+10 \mathrm{~m}+\mathrm{n}$ があるとき， l が 1 增すためには $\mathrm{m} は 1 〜 9$ までの数をとり，そ の間に nは $1 \sim 9$ までの数を何れも10個ずつ出現 する可能性があり，このときnにおける $1 〜 9$ ま での各数の出現頪度は相等しいと仮定することが できる。したかって，読み取りが正しければ末端 位の数字の出現頪度は平等でなければならない。
計測結果が上記の仮説に適合するか否かを， $x^{2}-$ test Kよって判定し得るであろ5.

末端位数分布の調查対象とした計測值は，記録 数字を読みとる人口数值，指示針が固定されてい る身長および気温の計測值，指示針が動摇してい る体重および血压の計測值である.

人口数は，昭和 23 年 30 年にわたる 8 年間の 46 都道府県における出生, 死亡, 死産, 婚姻および 離婚の人口動態を対象としたものである。それぞ れの人口数の末端位数は, 46 都道府県数の 8 年分 すなわち 368 個の数值が 得られる. $0 \sim 9$ までの 10個の末端位数が平等に分布するならば，その期 待值は 36.8 となる.

気温の計測值は, 気象庁の観椡に上るもので, 1 年間の毎日の最高気温, 最低気温およびその較 差である.末端位数は小数点第 1 位の值とした。

身長および体重の測定は, 幼稚園から大学にわ たって行ない，年令による，また学校による誤差 の在り方を検討した。調查校は幼稚園 6 園，小学 校 6 校, 中学校 6 校, 高等学校 6 校, お゙よび大学 1 校である。

身長計の最小目盛は $1 / 10 \mathrm{~cm}$, 体重計は $1 / 10 \mathrm{~kg}$ の計器を用い，いずれの末端位数す，小数点第 1 位の值とした。

血圧の測定值は壮年体力測定時に得たすので， 2 人の検者によって测定を行なった。血圧計の最 小目盛は $2 \mathrm{mmHg}$ であり, 計測值の末端位数は第 1 位の值である.

いずれの計測值の末端位数についても，0９ の数值が平等に分布するものと仮定し，その分布 の状態を $\chi^{2}$ 㭘定した。

\section{III. 测定・㽢查の耤果}

\section{（1）人口の動態にみる計数值}

人口を数えるような場合は，末端位が個数によ って定まりここれ個数以下の位に分割すること ができない，第 1 表は昭和 23年〜30年における 46 都道府県の出生, 死亡, 死産, 婚姻书上び蜼婚の 人口動態から久た末端位数 1 ～9 での出現数で ある.このときの $\chi^{2}$-test の值は, 死亡数を除け ばいずれも $5 \%$ ，あるいは $1 \%$ の有意水㫎 $\left(x^{2}\right.$ 值 16.919 及び21.666）よりも少なく，末端位数に偏 
第人口動怒統計值飞みられる末端位数の分布

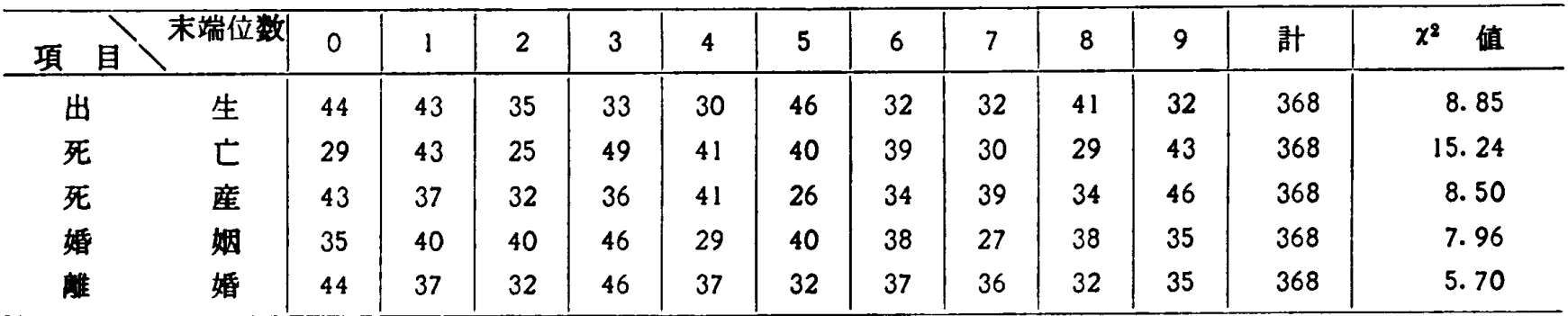

第2哀気温の計泪

\begin{tabular}{|c|c|c|c|c|c|c|c|c|c|c|c|c|}
\hline 項 目入末端数 & 0 & 1 & 2 & 3 & 4 & 5 & 6 & 7 & 8 & 9 & 計 & $x^{2}$ 值 \\
\hline 最高気温 & 30 & 28 & 28 & 34 & 49 & 48 & 30 & 35 & 32 & 49 & 360 & 16.19 \\
\hline 最低気温 & 34 & 47 & 37 & 34 & 35 & 30 & 26 & 35 & 45 & 40 & 360 & 10.14 \\
\hline 校 & 41 & 37 & 28 & 38 & 29 & 37 & 42 & 39 & 40 & 29 & 360 & 11.72 \\
\hline
\end{tabular}

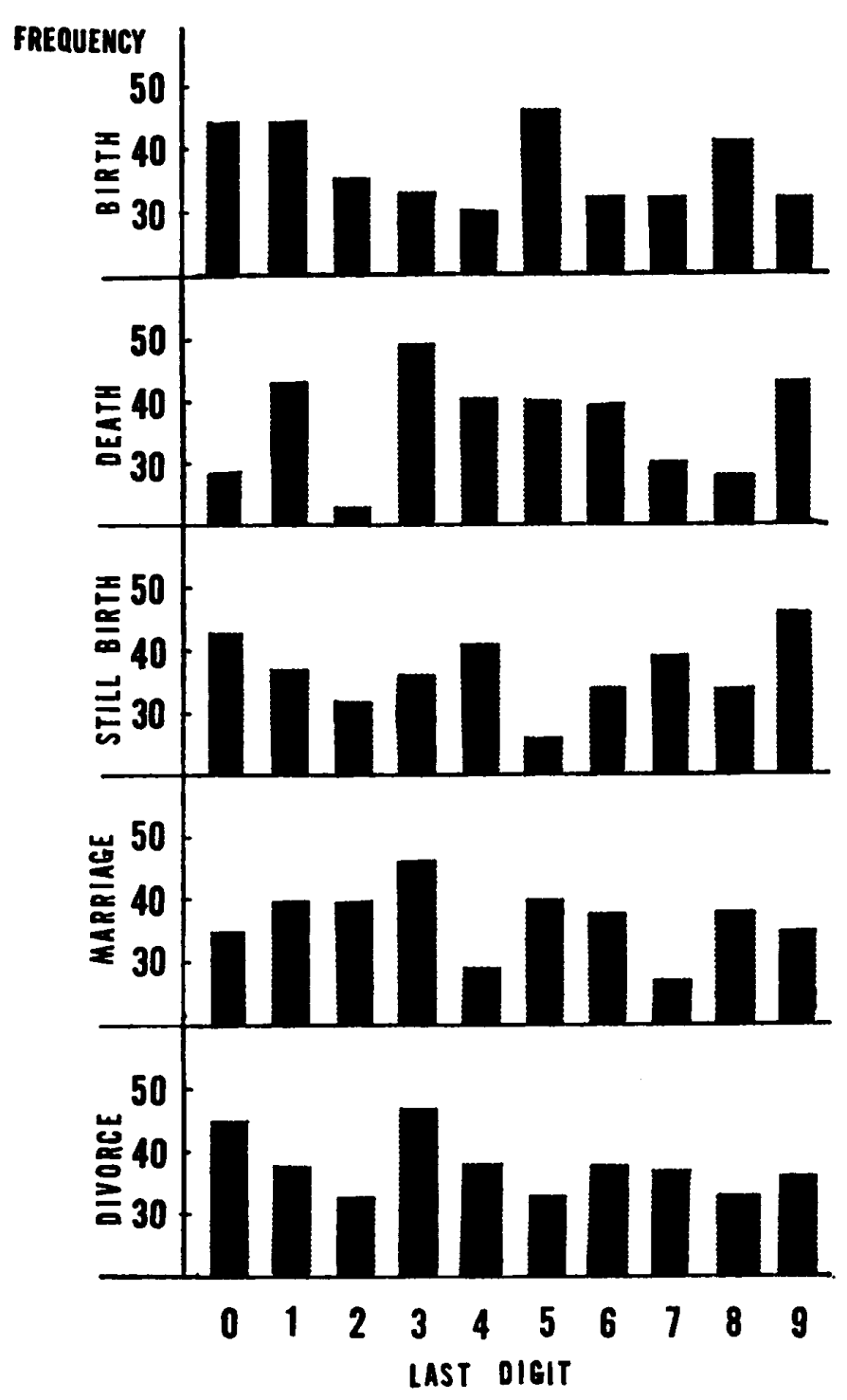

第1図人口動態統計数值沉みられる末端位数の分布
クがあるべきでないという仮説を満足せしめてい る.第1罒はこれをヒストグラムにして現わした ものである。

(2) 気温の読み

気温の記載は水銀柱の高さ，あるいは自記式の 場合は針先の記録を読み取るるのであり，フナロ グ的変化をデシタル量として読み取るるのであ る.この場合，観測が偏りなく正確に行なわれる ならば，末端位数の分布は $0 〜 9$ まで平等に分布 するとい5仮説を渾足させなければならない。

ここでもちいた気温の観測值は，気候観测者の ような曹阴家によって行なわれたものである。一 般に，温度の計測は最小目盛の $1 / 10$ を目测し得る ことになっている．気温測定の揚合はまず最小目 盛間の目測を行ない，ついで最小目盛，さらに上 位の峃位の目盛を読むならわしになっている。

このよ5にして行なわれた気温の観测测定值に みられる末端位数の 0 〜 9 まで分布を示したも のが第 2 表及び第 2 图である.

$\chi^{2}$-test の絬果は，いずれも $1 \%$ の危険度をむっ て，末端位数が平等に分行するとい5仮説が成立 する。

\section{(3) 身長の测定消}

身長計の下に淔江した人間である被計測体は, 心理的にも一様でないので，常に一定の被計測姿 势をとるとは限らず, 若干の凯動はやむを得な W. 


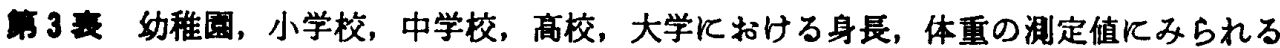
末端位数の分布度 (\%)

\begin{tabular}{|c|c|c|c|c|c|c|c|c|c|c|c|}
\hline & \multicolumn{5}{|c|}{ 身 } & \multicolumn{5}{|c|}{ 体 } \\
\hline & & 幼稚園 & 小学校 & 中学校 & 高 校 & 大 学 & 幼稚園 & 小学校 & 中学校 & 高 校 & 大 \\
\hline & 0 & 28.0 & 18.0 & 19.0 & 29.0 & 22.0 & 39.0 & 27.0 & 42.0 & 44.5 & 42.0 \\
\hline \multirow[t]{2}{*}{ 末 } & 1 & 4.0 & 6.0 & 6.5 & 4.0 & 6.0 & 1.5 & 5.0 & 1.0 & 2.5 & 5.0 \\
\hline & 2 & 9.0 & 10.0 & 11.0 & 8.0 & 12.0 & 7.0 & 9.0 & 5.0 & 3.5 & 9.5 \\
\hline \multirow[t]{2}{*}{ 端 } & 3 & 7.0 & 8.0 & 7.5 & 6.0 & 8.5 & 3.5 & 4.0 & 3.0 & 2.5 & 2.0 \\
\hline & 4 & 8.0 & 9.0 & 9.0 & 6.0 & 6.0 & 9.0 & 7.0 & 4.5 & 3.0 & 13.0 \\
\hline \multirow[t]{2}{*}{ 位 } & 5 & 11.0 & 13.0 & 11.0 & 15.5 & 16.0 & 21.0 & 22.0 & 29.5 & 31.0 & 7.0 \\
\hline & 6 & 8.0 & 9.0 & 9.0 & 7.5 & 7.5 & 5.0 & 10.0 & 4.5 & 3.0 & 7.0 \\
\hline \multirow[t]{3}{*}{ 数 } & 7 & 6.0 & 9.5 & 8.0 & 7.5 & 7.0 & 5.0 & 5.0 & 2.0 & 3.5 & 1.0 \\
\hline & 8 & 10.5 & 10.5 & 11.0 & 9.5 & 11.0 & 6.5 & 8.0 & 6.0 & 4.0 & 10.5 \\
\hline & 9 & 8.5 & 7.0 & 8.0 & 7.0 & 4.0 & 2.5 & 3.0 & 2.5 & 2.5 & 3.0 \\
\hline \multicolumn{2}{|c|}{ 計 } & 100.0 & 100.0 & 100.0 & 100.0 & 100.0 & 100.0 & 100.0 & 100.0 & 100.0 & 100.0 \\
\hline
\end{tabular}

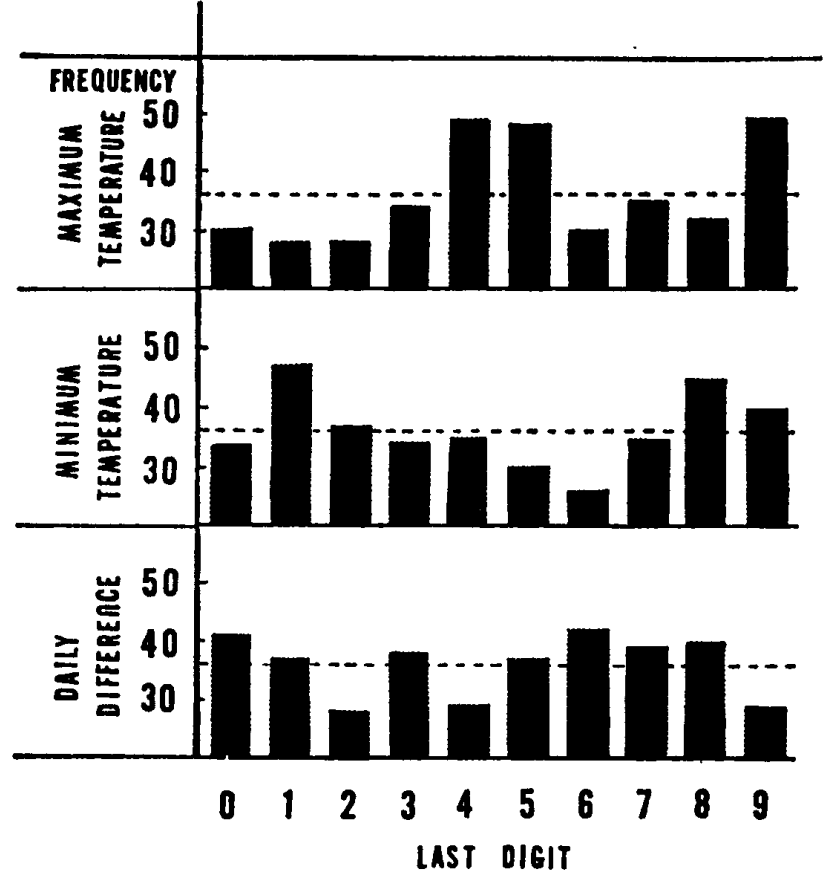

第 2 因最高，最低気温泪定值及ご較差の末端位 数の分布 (点線は期待值を示す)

幼稚園少から大学生までの身長，值重の計測結

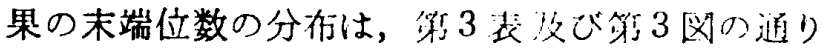
である.

末端位数が平等分布したものは筑 4 㳖に示すよ 5 に小学校では 1 校, 幼稚園では2 園であり，他 はすべて末端位数の分布平等の仮説を裹却し，识 差をもたらす何らの原因のあること思わせる。

身長については，幼稚園から大学まで末端位数 が 0 のものが最も多く，ついで 5 であった。この

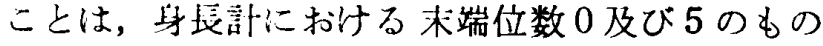

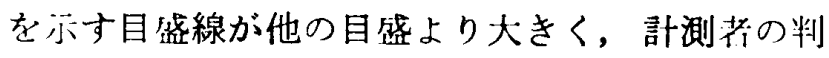
断がこれから誘引されるためであろう。

(4) 体重の計測について

体重の計測においては，末端位数の分布つ偏り は第 3 四にみられるよ5に，さらに甚しくなり， 本端位数が 5 である場合が多くなってくる．体重 测の場合は，指示針の停止が困難であり，その 形摇のために， $0 ， 5$ の目盛に誘引されるからで 占万弓。

位再の湘足值における末端位数が 0 と 5 に集中 す的接合は幼稚園中小学校上り，中学校，高等学 校の方が甚しい，このことは，学校がより上級に なるにしたがって测定を軽視しがちになるためと 考况ら机る。

訓测细は被計测者の墛度如何によって，大きく 変化与る，第 5 表は $\mathrm{A}, \mathrm{B}$ の中学校の佮重の测走: 值であり，第 6 表は $\mathrm{C}, \mathrm{D}, \mathrm{E}, \mathrm{F}, \mathrm{G}$ 中学のも

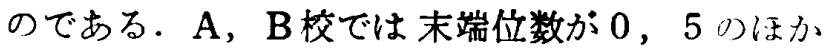
にも友ら机るが，C〜 G 校に於ては汪と儿どの束 端位数が 0 と 5 に限られており，後者の場合の計 测者はすべての末端位を 0 及び 5 の目盛に帰属せ しめている.この相違は計测者が 0 と 5 以外の傎 を無視するといら計り方の態度に上るものであ る.

第4 4 汹依，A，B 2 校の 1，2，3 年の体重测定 做に现われた末端位数の分布を百分辫にし，これ 


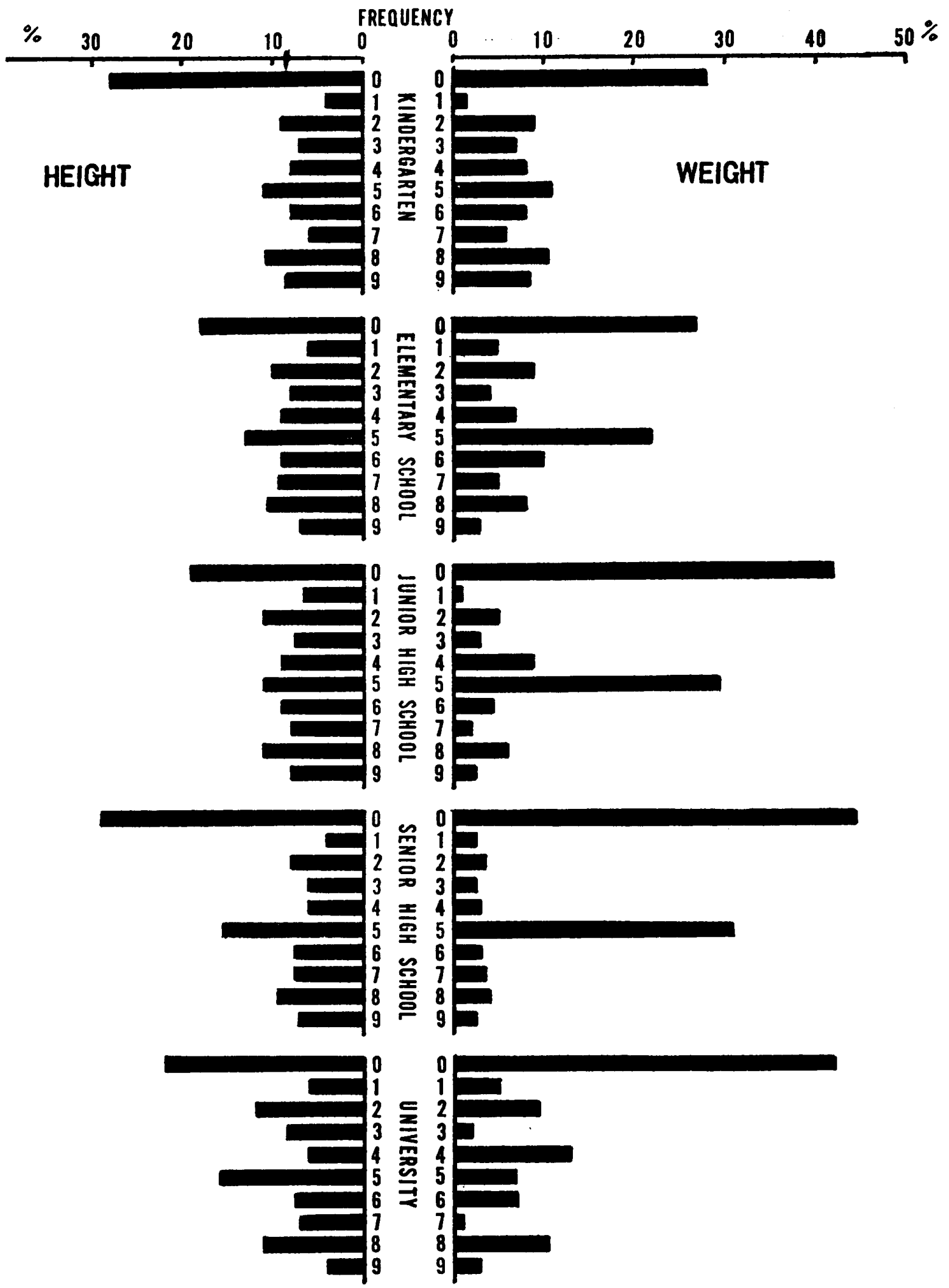

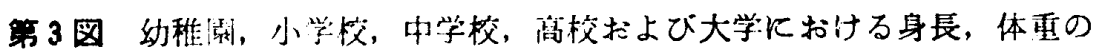
計测做にみられる末端位数の方存 


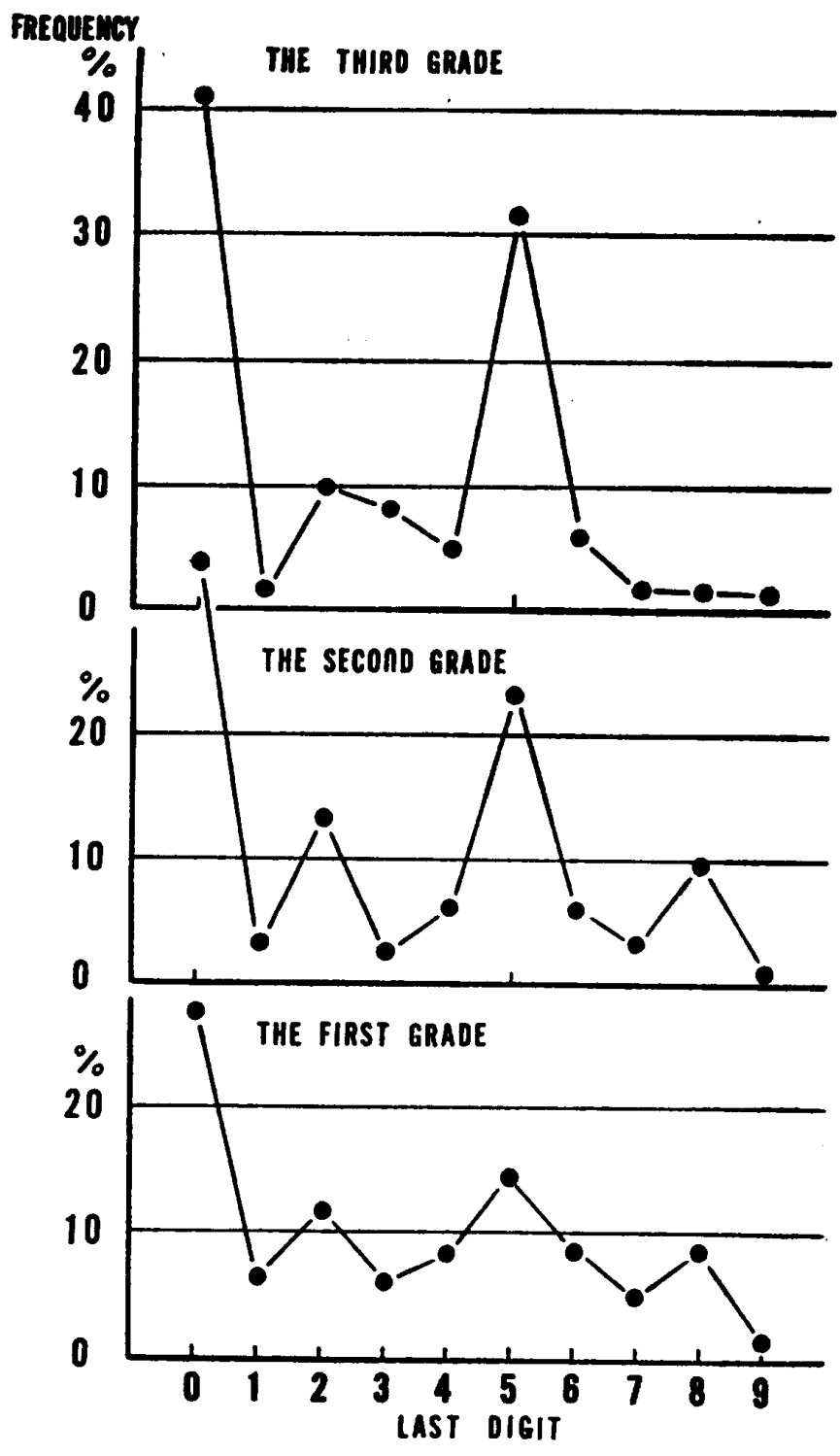

第4 図中学校 1，2，3学年における体車計測值の 本端位数分布
度幼稚園, 小学校, 中学校, 高校, 大学 における身長, 体重の測定值にみる末端 位数の分布

\begin{tabular}{|c|c|c|c|}
\hline & \multirow{2}{*}{ 敬湖定者蜘 } & $x^{2}$ & \multirow{2}{*}{ 值 } \\
\hline & & 身 長 & \\
\hline \multirow{6}{*}{$\begin{array}{l}\text { 幼 } \\
\text { 稚 } \\
\text { 國 }\end{array}$} & 99人 & 16.8 & $60: 2^{* *}$ \\
\hline & 65 & 13.8 & $960.1^{* *}$ \\
\hline & 30 & $81.5^{* *}$ & $102.4^{* *}$ \\
\hline & 179 & 73. $5^{* *}$ & $325.5^{* *}$ \\
\hline & 130 & $50.2^{* *}$ & 15.2 \\
\hline & 43 & $138.4^{* *}$ & $237.2^{* *}$ \\
\hline \multirow{6}{*}{$\begin{array}{l}\text { 小 } \\
\text { 学 } \\
\text { 校 }\end{array}$} & 124 & 6.9 & $24.1^{* *}$ \\
\hline & 462 & $45.8^{* *}$ & $87.8^{* *}$ \\
\hline & 1036 & $229.8^{* *}$ & $1501.3^{* *}$ \\
\hline & 1441 & $158.9^{* *}$ & $301.8^{* *}$ \\
\hline & 313 & $99.1^{* *}$ & $410.4^{* *}$ \\
\hline & 211 & $114.7^{* *}$ & $1183.0^{* *}$ \\
\hline \multirow[b]{2}{*}{ 中 } & 1393 & 88. $9^{* *}$ & $1922.4^{* *}$ \\
\hline & 1285 & $268.6^{* *}$ & $855.1^{* *}$ \\
\hline \multirow{2}{*}{ 学 } & 609 & $39.5^{* *}$ & $2536.3^{* *}$ \\
\hline & 655 & $95.9^{* *}$ & $1840.8^{* *}$ \\
\hline \multirow[t]{3}{*}{ 校 } & 100 & $124.0^{* *}$ & $247.2^{* *}$ \\
\hline & 119 & $252.5^{* *}$ & $481.4^{* *}$ \\
\hline & 127 & $25.5^{* *}$ & $413.8^{* *}$ \\
\hline \multirow[b]{2}{*}{ 菋 } & 490 & $64.8^{* *}$ & $163.8^{* *}$ \\
\hline & 759 & $62.4^{* *}$ & $2343.7^{* *}$ \\
\hline 等 & 141 & $25.4^{* *}$ & $173.2^{* *}$ \\
\hline 学 & 839 & 209. $2^{* *}$ & $2447.0^{* *}$ \\
\hline \multirow[t]{2}{*}{ 校 } & 566 & $230.8^{* *}$ & $1755.0^{* *}$ \\
\hline & 1221 & $1801.2^{* *}$ & $5487.6^{* *}$ \\
\hline 大 学 & 973 & $28.3^{* *}$ & $129.9^{* *}$ \\
\hline
\end{tabular}

を点描したものである。ここで見られるように， 学年が進むにつれ，末端位数がより多く 0 及び 5 に集中する傾的がある。このことはたとえ同一㭘 者による場合でも，体重のように動摇快に就及取 る必要のあるときは，被計测者の隹度が影紫する ことを示しており，したがって計測時には，当然 被計測者の管理が必要となってくる。

(5) 血正測定について

血圧は操作しながら計らなければならない。し かも動摇している水銀柱の目盛を挖み耿ることに なるので，目盛の読み取り判断も困難である。一
般の血圧計の目盛は $1.0 \mathrm{~cm}$ の間を $2 \mathrm{~mm}$ ずつの 5 目盛に刻んであり，奇数仙を含めたデジタル量と して誖み取らなければならない。したがって目測 によらなければならない部湘值もでてくることに なる、そのために誤差はますます多くなるので， 1〜2 $\mathrm{mmHg}$ の変化もさして意味をなさない。

第7 表は，血压測定における末端位の数字の分 布であり，第 5 図はそのヒストグラフである。一 般の計湘值は 0 と 5 に集まるが，ここでは 5 等分 目盛を付しているので，术端位数は $0 ， 2 ， 8$ な との偶数に集まり，末端位数 5 を示するのが少な 
第 5 A，B 2 校の学年别化みた末端位数の分布

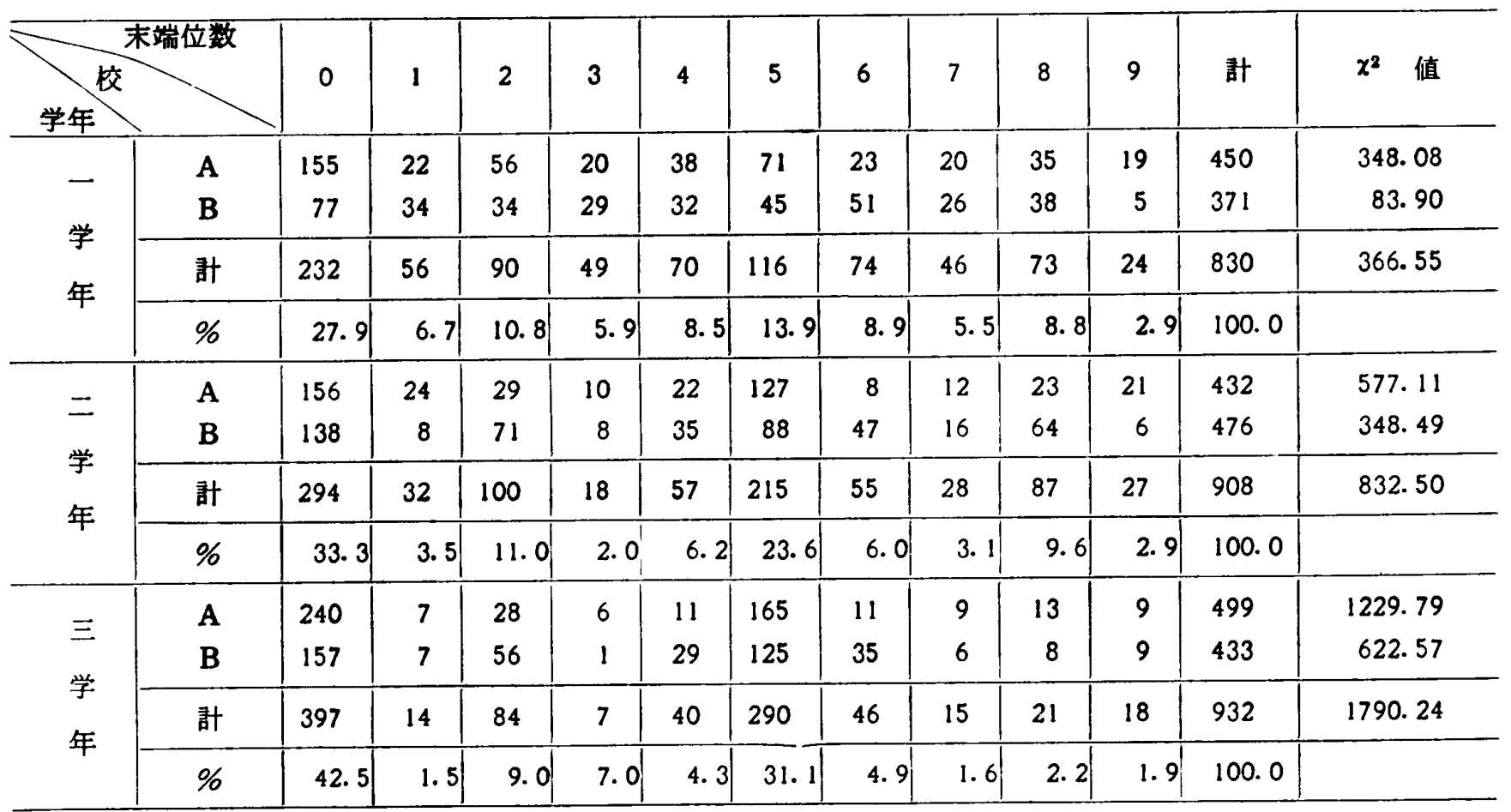

第6 表中学校における体重泪定值の末端位数集皘分布

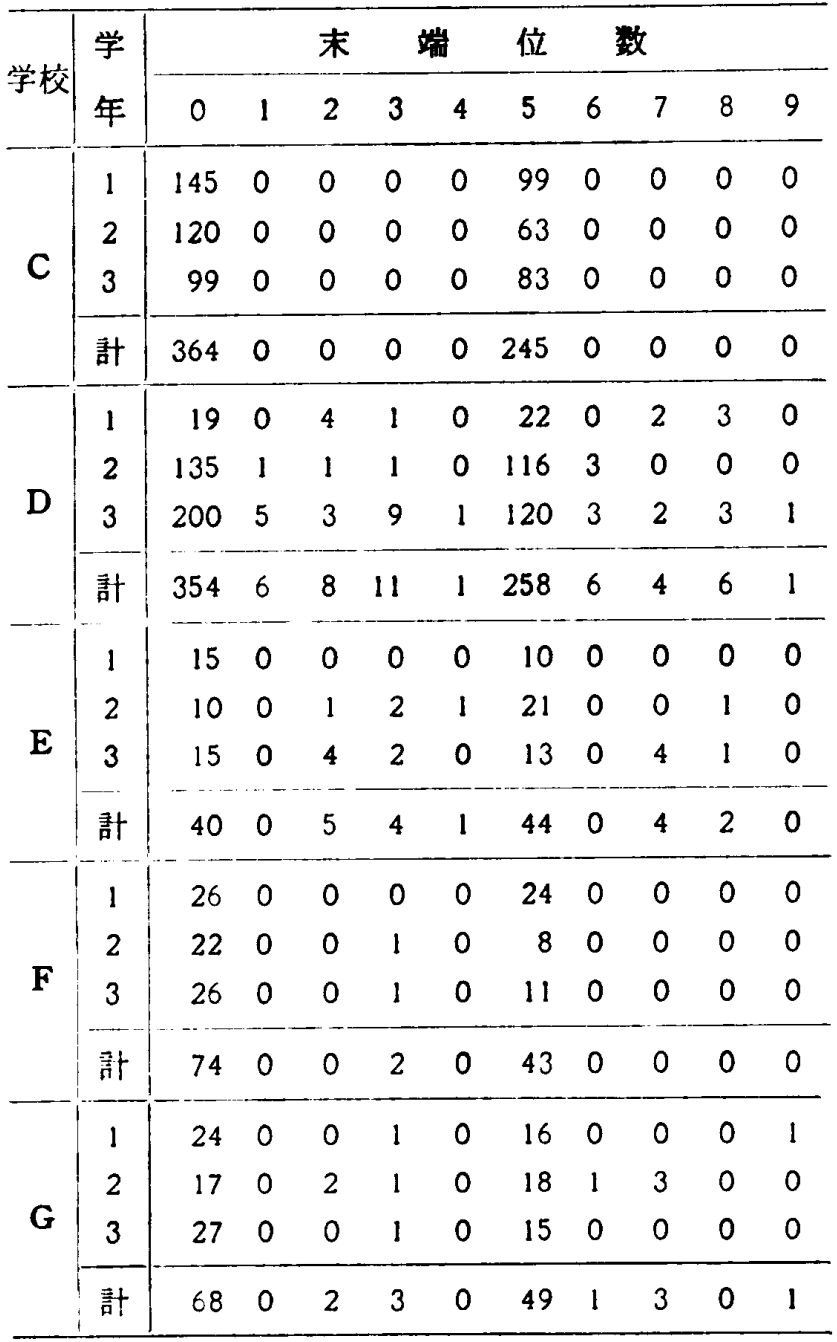

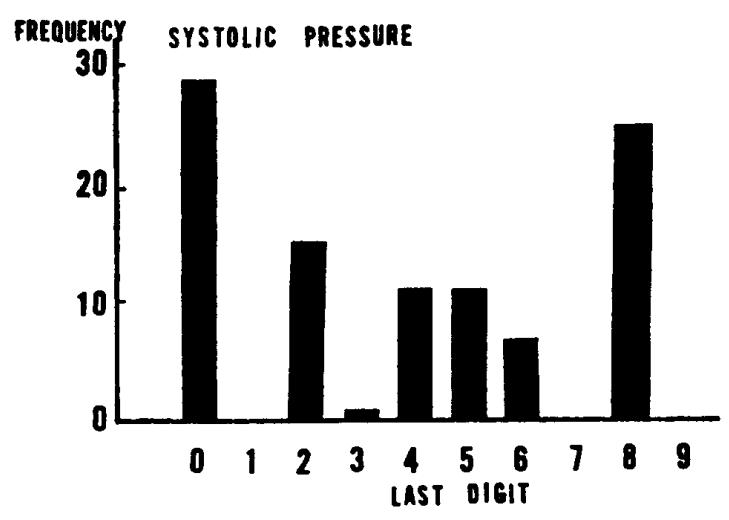

FREQUENCY

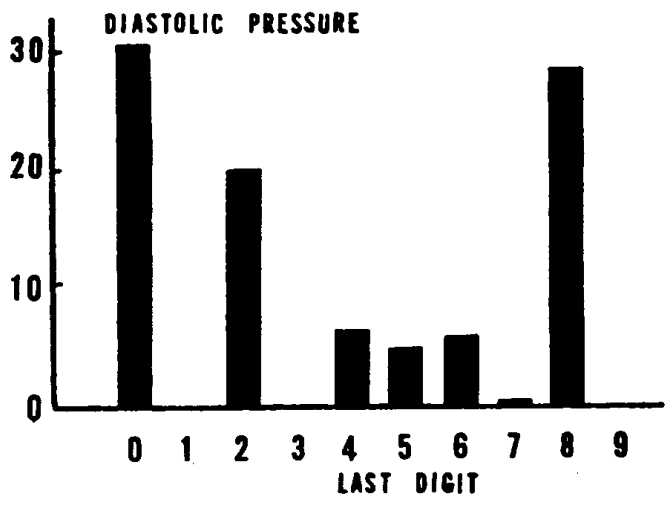

第5図最高血压值および最低血圧值に みる末端位数 


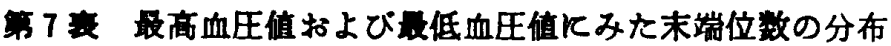

\begin{tabular}{|c|c|c|c|c|c|c|c|c|c|c|c|c|c|}
\hline 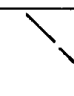 & 位数 & 0 & 1 & 2 & 3 & 4 & 5 & 6 & 7 & 8 & 9 & 計 & $x^{2}$ 值 \\
\hline 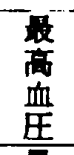 & $\begin{array}{l}\mathbf{n} \\
\%\end{array}$ & $\begin{array}{l}62 \\
28.8\end{array}$ & $\begin{array}{l}0 \\
0\end{array}$ & $\begin{array}{l}33 \\
15.2 \\
\end{array}$ & $\begin{array}{l}2 \\
0.9\end{array}$ & $\begin{array}{l}25 \\
11.5\end{array}$ & $\begin{array}{l}24 \\
11.1\end{array}$ & $\begin{array}{c}16 \\
7.4 \\
\end{array}$ & $\begin{array}{l}1 \\
0.5\end{array}$ & $\begin{array}{l}54 \\
24.9 \\
\end{array}$ & $\begin{array}{l}0 \\
0\end{array}$ & $\begin{array}{l}217 \\
100.0\end{array}$ & 212.07 \\
\hline $\begin{array}{l}\text { 最 } \\
\text { 低 } \\
\text { 衁 }\end{array}$ & $\begin{array}{l}\mathbf{n} \\
\%\end{array}$ & $\begin{array}{l}65 \\
30.5\end{array}$ & $\begin{array}{l}0 \\
0\end{array}$ & $\begin{array}{l}43 \\
20.2\end{array}$ & $\begin{array}{l}3 \\
1.4\end{array}$ & $\begin{array}{c}15 \\
7.0\end{array}$ & $\begin{array}{c}11 \\
5.2\end{array}$ & $\begin{array}{c}13 \\
6.1\end{array}$ & $\begin{array}{l}2 \\
0.9\end{array}$ & $\begin{array}{l}61 \\
28.6\end{array}$ & $\begin{array}{l}0 \\
0\end{array}$ & $\begin{array}{l}213 \\
100.0\end{array}$ & 566.72 \\
\hline
\end{tabular}

くなっている。

\section{IV.}

各測定值は，それそれに誤差を含むものであ クこのことは测定するといら行為に背負された 必然ではあるが，哄差平等の法則に従5限り，必 ずしも母集団の推定值をくるわせるものではな い.

身長や体重のよ5な体格の測定では，その测定 対象となる身長や体重が，1日の身体的な条件， すなわち身長では，午前の值と午後の值の異なる こと，体重では食事や排泄などにより異なること などによって変化するものであるから，ある特殊 な目的をもって测定する場合を除けば， $3 \sim 4$ 桁 の測定值の末端位数の如何が大きな誤差として問 題になることはない，問題はむしろ詔り方の偏[问 にある。

大数計測の場合，その末端位数は $0 〜 9$ まで平 等に分布すべきものであるという仮説を設定し た。

集団の身長や体重を計測する場合，この仮説か らの離脱度によって検者の能力や被測定者の態度 などを推察することもできる。ここでは仮設から の離脱度を $\chi^{2}$-testで検定したここの仮説は当然の ことながら人口動態にみられる諸数值及び表阴技 術者による気温の梳みなどにおいては，満足され ている。

それぞれの测定湖にみられる誤差の発生度は， 第 8 表にまとめたよ5に被测物（大）の動披の篮 度に影響されてくる，人口の数表を読むよ5な場 合は原則的に誤りはない。しかし計测者の視力， 注意力，意欲など一般的原因によって誤読，䛊記 の類宾む增減するであろ5が，これらは北特異的
第 8 表 計測の難易度の型

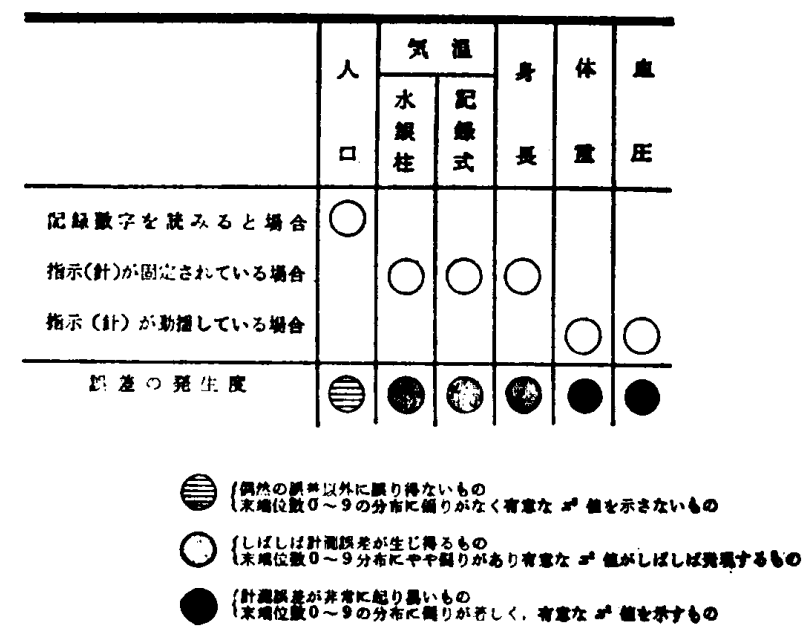

な誤差原因であり，さらに偶然の誤差もあろ5。 これに対して，温度計の読み取りは，極めて迅速 に温度が変化するような場合はやむを得ないが， 问じょうな条件においても，梳棸取り方がよりし ばしば誤差の原因となり得るものと考えられる。 血王を测るような場合は，血压本来の在り方によ って血下計の水銀柱は常に動摇しており，その間 に水銀柱を読み取らなければならないとい5团難 さをもっている。

したがのて，人口部数，身長のように指示点が 固定さ记得る場合の計测と，血压のよ5に指示点 が動㩲している場合の誤差の発生は，おのずから 異なってくるであろ5し，体重，胸四などの計测 はこの川䦎に属するものとも溚えられる。

一·般に $\chi^{2}$-test の場合，標本数が多くなるとき， 理論做からの倔差は標本数に比例して增加与るも のでは占く，むしろ減少されるのが普通である。

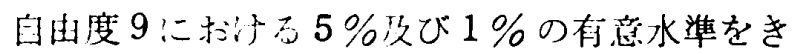
めそ和の倠は，それぞれ 16.919，21.166である が， $\chi^{2}$ の倠は標本数方大きくなれば，期待值 $\mathrm{m}$ も 
第 8 衰 標本数と $x^{2}$ 值の関係

\begin{tabular}{|c|c|c|c|c|c|c|}
\hline \multicolumn{2}{|c|}{ 標本数 } & 100 & 200 & 500 & 800 & 1000 \\
\hline \multicolumn{2}{|c|}{ 期待值 } & 10 & 20 & 50 & 80 & 100 \\
\hline \multirow{3}{*}{ 末 } & 0 & 28 & 56 & 140 & 244 & 280 \\
\hline & 1 & 7 & 14 & 35 & 56 & 70 \\
\hline & 2 & 10 & 20 & 50 & 80 & 100 \\
\hline \multirow[t]{2}{*}{ 端 } & 3 & 6 & 12 & 30 & 48 & 60 \\
\hline & 4 & 8 & 16 & 40 & 64 & 80 \\
\hline \multirow[t]{2}{*}{ 位 } & 5 & 15 & 30 & 75 & 120 & 150 \\
\hline & 6 & 9 & 18 & 45 & 72 & 90 \\
\hline \multirow[t]{3}{*}{ 数 } & 7 & 6 & 12 & 30 & 48 & 60 \\
\hline & 8 & 8 & 16 & 40 & 64 & 80 \\
\hline & 9 & 3 & 6 & 15 & 24 & 20 \\
\hline \multirow[t]{2}{*}{$x^{2}$} & 值 & 44.8 & 89.6 & 224.0 & 358.4 & 448.0 \\
\hline & & $\times 1$ & $\times 2$ & $\times 5$ & $\times 8$ & $\times 10$ \\
\hline
\end{tabular}

大きくなるので，標本数による佌は一応相敉され ているとみなすことができる。いま栖本数 100 の 場合の末端位数が第 9 表のよ5に分行した之きの $\chi^{2}$ の) 估は 44.8 であり，栖本数が 2 倍， 5 倍， 8 倍，10倍になりながらも，その偏筑の在り方が同 じ割会であるならば，それぞれの和们もまた 2 倍， 5 倍，8倍，10倍となる。このことは恓本数 が多くなることは，上り期待栣に近い任が上り高 頻度で出現するものであるという安全性な湦越し

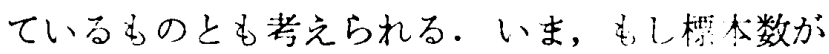

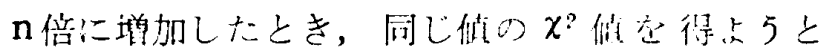

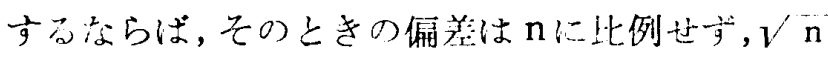
に此例しなければならない。

さらに端位数の分布から，測边做心䘯度を検 討一る場合，测定做をどの程度の木端位まで計測 するかによっても，末端位数の分布が異なってく る.すなわち計测の精度を落として，読夕取り誤 差を少なくするか，あるいは読み取りにくさによ る䛊养の発生をみこんで，1析位を下げて精度を 高的るかによっても，末端位数の分有が巽なって くる。第10表に示した重苚跳の計測但は，末端位 を $\mathrm{mm}$ の羊位まで計測せす゚に，流み取りやない $\mathrm{cm}$ の监位で切りすてて测定したものであるが，この 場合の末端位数の分材は 0 〜 9で添平等に分 布しており，測定做の精度を閣题にしなけ虬は，

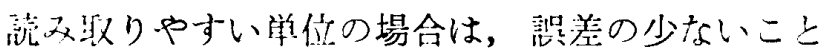
名标さる。
第 10 奉 垂直跳泪定值にみる末端位数の分布

\begin{tabular}{|c|c|c|c|c|}
\hline 木端位数】組 & A & B & $\mathrm{C}$ & 計 \\
\hline 0 & 11 & 27 & 25 & 63 \\
\hline 1 & 17 & 27 & 19 & 63 \\
\hline 2 & 12 & 27 & 19 & 58 \\
\hline 3 & 11 & 37 & 20 & 68 \\
\hline 4 & 15 & 23 & 15 & 53 \\
\hline 5 & 20 & 29 & 33 & 82 \\
\hline 6 & 10 & 23 & 21 & 54 \\
\hline 7 & 11 & 20 & 16 & 47 \\
\hline 8 & 9 & 23 & 18 & 50 \\
\hline 9 & 4 & 24 & 14 & 42 \\
\hline 計 & 120 & 260 & 200 & 580 \\
\hline$\chi^{2}$ 值 & 14.83 & 7.69 & 13.90 & $20.83^{*}$ \\
\hline
\end{tabular}

* $\mathrm{p}<0.05$

計測をする場合，デジタルな計数データでは， 計測䛊差は少なく，作為的な意困がはらわれない 限り，本端位数は $0 \sim 9$ までの数值に平等に分布 している。しかし，フナログ的な計量データで, かつ被测定物や测定器に動採が里:じてているけで計 測を行な5場合は，測定值の精度を间める。

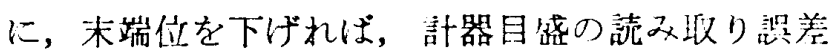
や，目盛間の目測による的等を主:じることになり やすい，計澌の目的に合わせ心精度を選択する 際，最小位の末端数の分布からも，1つの手がか りを得ることができょ5。

\section{V. 結語}

諸種計測についての大数標本において，末端位 の数は 0 〜 9での数字が平等に分布すべきであ るという仮定のもとに，竍测データの末端位数の 分布を $\chi^{2}$-test（カイ二乘テスト）で検討した。計 测は目盛の読又仅り方の難易はスケールのとり方 とともに，被計测物（体）によってもたらされる ものと仮定した。

(1) 人口動隹統計の上5に，報告に記载され， 計算されるものは，偶然の不可避的な识差以外に 佂りを生ずる原因はなく，末端位数は末端位数平 等分布の仮説を満是させる。

(2) 気像唄測の技術者によって行なわれる気温 の言测データにおいても本端位数の分布はほぼ仮 説を满足している。 
（3）身長の計測データにおいては，一般に末端 位数が，0，5に集まってく可傾向がある．体重 に扎てて、この傾向はさらに著しくなる。

体重の計測にあたって，データの末端位数の 0 , 5 に菓まってくる度合は，中学校においては学年 の進むにつれて著しくなる。このことは，たとえ 同一検者が計剆する時でも，学年が進さにつれ て，被計測者の管理がむすかしくなり，指示の導 守が困難なることを物語っている．

（4）学校の身体検查時に行なわれる身長，体重 などの計測データは学校すなわち，計测者によっ て甚しく異なる場合がある。ある学校において は，末端位数がほとんど $0 ， 5$ の場合がありここ れによって，たとえ計測值の平均值の信頼度を娍 ずることはないが，計测者の注意の指向を推察す ることができる。

（5）血压の測定については，下級指示標示が上 級指示標示の 5 等分目盛に印されているために,
$0 ， 8$ に集まり，目測によって行なわれる奇数の末 端位数を示すものは極めて少ない。この傾向は最 大血茞よりも最小血压の测定值に执いて著しい。

\section{文献}

1）藤田 檿：「大きさの見皘りに及ほす銀練効果の娭 封」, 研究紀要, 日本大学人文学科研究所, 154 182, 1967.

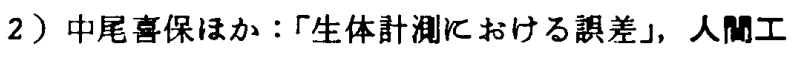
学, 8〜3, 141 146, 1972.

3 ）大鼠正光：「人間の錯俱」，人问工学，3１，16～ 22, 19 22, 1967.

4 ）佐藤次郎：「濆定作業飞おける諆差飞ついて」，人问 工学, 8〜3, 147〜152, 1972.

5) 高木辵一:「視觉と視賞表示」, 人网工学, 4〜1，1 ６, 1973.

6) 吉田正昭訳編：「旪国心理学」, 誠信葲房, p. 284, 1968. 